\title{
Relationship between Public Education Expenditures and Economic Growth of Pakistan
}

\author{
Muhammad Aqil, Syed Fazal Aziz, Muhammed Dilshad, ${ }_{3}$, Seemab Qadeer 4 \\ ${ }^{\prime}$ (Assistant Professor, Commerce Department, Defence Authority Degree College, Karachi, Pakistan) \\ ${ }^{2}$ (Senior Executive Vice President(Retd), National Bank of Pakistan, Karachi, Pakistan) \\ ${ }^{3}$ (Lecture, Government Degree College, Paretabad, Hyderabad, Pakistan) \\ ${ }^{4}$ (Assistant Professor, Economics Department, Defence Authority Degree College, Karachi, Pakistan)
}

\begin{abstract}
Education is one of the most significant factors that positively affect economic growth. Education creates value addition in human capital by means of skills and experience. Therefore, this is pertinent to recognize the role of education in the economic growth of a country. The government plays vital role in boosting up the level of education for the nation by means of investment in this sector. This paper analyzes the effect of public sector education expenditures on economic growth of Pakistan. The results show that public sector expenditures have a significant impact on GDP per capita of the country.
\end{abstract}

Keywords: Economic Growth, GDP per capita, Human Capita, Public Sector Expenditure, Public Education Expenditures

\section{Introduction}

Economic growth is considered inevitable for economic and social development. Many studies have been conducted to find out the factors which increase the economic growth. Economic Growth is measured by Gross Domestic Products of a country. There are many ways to increase the GDP growth rate which include foreign direct investment, investment in capital goods, better capacity utilization etc. However, education is considered as one of the effective ways to influence the growth. Education has been treated as an important determinant of economic growth since the time of Adam Smith. The economists have been considering Education as a form of investment in human development which improves the skills and ability of people to earn efficiently. As a result, the production of goods and services increases.

Many models have been made to address the relationships between education and economic growth such as Psaharoupolous, [1]; De Meulmester et. al., [2]; and Jorgenson and Fraumeni, [3]. They concluded that education raises the level of economic growth by means of improving the productivity of factors of production. The human capital theory also endorses that education benefits the economy and individual both.

Pakistan is one of those countries where the literacy rate is very low as compared to other developing nations. The Pakistan Education Statistics 2007-08 reveals the fact that a total of 7,242 new institutions were added in a year. As a result, the total number of institutes increased to 231,289 in the country. Out of total institutions, 164,579 are in public sector and 81,103 in private sector. The literacy rate in Pakistan was just $69.66 \%$ and Pakistan's rank is $159^{\text {th }}$ out of 177 countries [4]. The following picture displays the evolution of literacy rate in Pakistan.

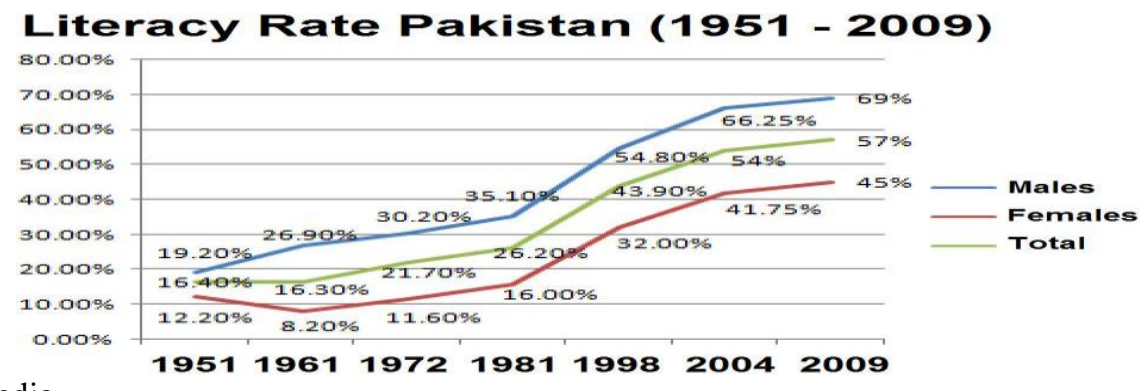

Source: Wikipedia

Therefore, this is inevitable for Pakistan to improve the level of education in the country. For this purpose, the primary responsibility lies on the shoulders of government. However, the public sector expenditures on education had been very low over a period of time. 
Public sector expenditures help increase the level of education in the country. As a result, they boost up the economic growth. The objective of this paper is to find out the relationship between public sector education expenditures and economic growth of Pakistan.

\section{Literature Review}

Becker, Murphy and Tamura (1990) found that education expenditures since 1960 had been a significant factor that caused the growth in per capita incomes for around hundred countries. In Pakistan, Aziz, Khan and Aziz, [5] concluded that the impact of higher education on economic growth was significant. Some other researchers also derived the same results as Jung and Thorbecke,[6] in Tanzania and Ogujiuba and Adeniyi [7], in Zambia, Nigeria and Chandra, in India[8]. However, Nurudeen and Usman [9] found that the impact of education expenditures on growth is negative.

\section{Research Methodology}

The data from 1971 to 2012 has been obtained for public education expenditure as a percentage of GDP [10] and for GDP per capita [11]. Public education expenditure (PSE) is the independent variable and GDP per capita is dependent variable. Simple linear regression model is run to establish the relationship between the variables. The following hypothesis is established:

Ho: There is no significant relationship between public education expenditures and GDP per capita H1: There is a significant relationship between public education expenditures and GDP per capita.

The econometric model is as follows:

GDP_PC $=\mathrm{a}+\mathrm{b}$ PS_ON_ED

Where

GDP_PC $=$ Gross Domestic Products Per Capita

$\mathrm{a}=$ intercept

PS_ON_ED= Public Sector Expenditures on Education $\mathrm{b}=$ Slope

\section{Data Analysis And Results}

The correlation between the variables is as follows:

Correlations

\begin{tabular}{|ll|r|r|}
\hline & PS_On_ED & GDP_PC \\
\hline PS_On_ED & Pearson Correlation & 1 & $.335^{*}$ \\
& Sig. (2-tailed) & & .046 \\
& $\mathrm{~N}$ & 37 & 36 \\
\hline GDP_PC & Pearson Correlation & $.335^{*}$ & 1 \\
& Sig. (2-tailed) & .046 & \\
& $\mathrm{~N}$ & 36 & 41 \\
\hline
\end{tabular}

*. Correlation is significant at the 0.05 level (2-tailed).

After running the regression model, the following results are derived:

Variables Entered/Removed ${ }^{\text {b }}$

\begin{tabular}{|l|l|l|l|}
\hline Model & Variables Entered & Variables Removed & \multicolumn{1}{|c|}{ Method } \\
\hline 1 & PS_On_ED & Enter \\
\hline
\end{tabular}

a. All requested variables entered.

b. Dependent Variable: GDP_PC

Model Summary

\begin{tabular}{|l|r|r|r|r|}
\hline Model & $\mathrm{R}$ & \multicolumn{1}{|c|}{ R Square } & Adjusted R Square & $\begin{array}{c}\text { Std. Error of the } \\
\text { Estimate }\end{array}$ \\
\hline 1 & $.335^{\mathrm{a}}$ & .112 & .086 & 25244.71685 \\
\hline
\end{tabular}

a. Predictors: (Constant), PS_On_ED

\begin{tabular}{|ll|r|r|r|r|r|}
\hline Model & & Sum of Squares & Df & Mean Square & F & Sig. \\
\hline 1 & Regression & $2.743 \mathrm{E} 9$ & 1 & $2.743 \mathrm{E} 9$ & 4.304 & $.046^{\mathrm{a}}$ \\
& Residual & $2.167 \mathrm{E} 10$ & 34 & $6.373 \mathrm{E} 8$ & & \\
& Total & $2.441 \mathrm{E} 10$ & & 35 & & \\
& & & & \\
\end{tabular}


a. Predictors: (Constant), PS_On_ED

b. Dependent Variable: GDP_PC

\begin{tabular}{|c|c|c|c|c|c|c|}
\hline \multicolumn{7}{|c|}{ Coefficients $^{\mathrm{a}}$} \\
\hline \multirow{2}{*}{\multicolumn{2}{|c|}{ Model }} & \multicolumn{2}{|c|}{ Unstandardized Coefficients } & \multirow{2}{*}{$\begin{array}{c}\text { Standardized } \\
\text { Coefficients } \\
\text { Beta }\end{array}$} & \multirow[b]{2}{*}{$\mathrm{T}$} & \multirow[b]{2}{*}{ Sig. } \\
\hline & & B & Std. Error & & & \\
\hline \multirow[t]{2}{*}{1} & (Constant) & -32911.268 & 26365.682 & & -1.248 & .220 \\
\hline & PS_On_ED & 23142.649 & 11154.928 & .335 & 2.075 & .046 \\
\hline
\end{tabular}

a. Dependent Variable: GDP_PC

\subsection{Interpretation of results}

From the above analysis, this is clear that there is a strong correlation between the variables.

The value of R square shows that there is around $11 \%$ variation in GDP due to public sector expenditures on education. The value of $\mathrm{F}$ is high with 0.046 level of significance. It means that the variable used is fit for the model. Further, the value of $t$ also has $p$ value equal to 0.046 and if we reject the null hypothesis, the probability of committing type I error is just $4 \%$ which is almost negligible. The results of coefficients form the following equation:

\section{GDP_PC $=-32911.268+23142.649$ PS_ON_ED}

The equation reveals that if there is no public sector expenditures, the GDP per capita will be negative which is not theoretically justified. It further explains that if there is a $1 \%$ rise in public education expenditure, the GDP per capita will rise by Rs.23,143. However, in order make the GDP per capita positive, the public education expenditures should be around $1.43 \%$ of GDP.

\subsection{Decision on Hypothesis}

Since the value of $t$ is within the $5 \%$ confidence interval, we reject the null hypothesis and conclude that there is a significant relationship between Public education expenditures and GDP per capita.

\section{Conclusion}

On the basis of above analysis, we conclude that there is a significant impact of public sector education expenditures on GDP per capita. Higher the public education expenditure, greater the GDP per capita and vice versa.

\section{References}

[1] Psacharopolous, G. Returns to Education: A further international update and implications. Journal of Human Resources, 1988. 20 $-4,893-921$.

[2] De Meulmester, J. C., \& Rochet, D., A causality analysis of the link between higher education and economic development. Economics of Education Review, 1995. vol.144 (4), 351-361.

[3] Jorgenson, H., \& Fraumeni, M. Investment in education and U.S. economic growth. Netherlands: Kluwer Academic Publishers. 1998

[4] http://finance.gov.pk/survey/chapter_10/10_Education.pdf

[5] Aziz, Babar; Khan, Tasneem and Aziz, Shumaila GC, "Impact of Higher Education on Economic Growth of Pakistan", University Faisalabad, MPRA Paper No. 22912, 2008.

[6] Jung, Hong-Sang and Thorbecke, Erik, "The Impact of Public Education Expenditure on Human Capital, Growth, and Poverty in Tanzania and Zambia: A General Equilibrium Approach", IMF Working Papers, August 2001.

[7] Ogujiuba, Kanayo and Adeniyi, Adenuga 2005. "Economic Growth And Human Capital Development: The Case Of Nigeria", Macroeconomics 0508023, EconWPA.

[8] Chandra, Abhijeet "Does Government Expenditure on Education Promote Economic Growth?An Econometric Analysis" Jamia Millia Islamia (Central University), New Delhi, MPRA Paper No. 25480, August 2010

[9] Nurudeen, Abu and Usman, Abdullahi 2010, "Government Expenditure And Economic Growth in Nigeria, 1970-2008: A Disaggregated Analysis", Business and Economics Journal, Volume 2010: BEJ-4.

[10] http://data.worldbank.org/country/pakistan

[11] http://www.econstats.com/weo/V007.htm 